\title{
RESILIENSI ORANGTUA YANG MEMILIKI ANAK BERKEBUTUHAN KHUSUS DI MASA PANDEMI
}

\author{
Rahma Kusumandari', Isrida Yul Arifiana ${ }^{2}$, Janata Saprida ${ }^{3}$, Abad Gading ${ }^{4}$ \\ Email: rahmakusumandari@untag-sby.ac.id ${ }^{1}$ \\ Fakultas Psikologi Universitas 17 Agustus 1945 Surabaya $a^{1,2,3,4}$
}

\begin{abstract}
Abstrak
Masa pandemi tentunya memberikan dampak tersendiri bagi orangtua yang memiliki anak berkebutuhan khusus. Salah satu dampak yang paling terasa berat adalah tidak adanya akses untuk melakukan terapi secara langsung. Selain itu, karena semua siswa harus belajar di rumah maka orangtua yang harus mengambil peran untuk melakukan pendampingan belajar. Kondisi tersebut tentunya menimbulkan kesulitan tersendiri bagi para orangtua, terutama bila mereka belum terbiasa melakukan pendampingan secara mandiri pada anaknya yang berkebutuhan khusus. Untuk dapat mengatasi kesulitan-kesulitan tersebut tentunya dibutuhkan resiliensi dari para orangtua. Tujuan dari penelitian ini adalah untuk mengetahui gambaran resiliensi para orangtua yang memiliki anak berkebutuhan di masa pandemi. Metode yang digunakan dalam penelitian ini adalah kuantitatif deskriptif. Alat ukur yang digunakan adalah skala resiliensi yang disusun oleh peneliti dengan mengacu pada konsep teori pengasuhan dari Davis (1999).
\end{abstract}

Kata Kunci : Resiliensi, Orangtua Anak Berkebutuhan Khusus, Pandemi Covid-19

PENDAHULUAN

Pada awal tahun 2020, Dunia dikejutkan dengan adanya wabah virus Corona atau kita kenal dengan Covid-19 yang hingga saat ini telah menginfeksi hampir seluruh negara di Dunia. Dalam kurun waktu 9 bulan sejak awal Maret 2020, virus corona telah menyebabkan 46.840 .783 kasus dan 1.204 .028 kematian (https: https://covid19.who.int/). Dampak dari adanya pandemi Covid-19 menyebabkan permasalahan dalam berbagai sektor diantaranya ekonomi, pendidikan, sosial, keamanan hingga hal-hal yang berkaitan dengan problem kesehatan fisik dan psikologis seseorang. Selain menyebabkan beberapa permasalahan, adanya pandemi Covid-19 juga membuat masyarakat untuk beradaptasi dengan situasi baru. Penyesuaian tersebut mencakup berbagai perilaku hidup sehat dengan menggunakan masker serta cuci tangan, perilaku dalam kegiatan pendidikan yang dilakukan secara online (daring), perilaku pada aktifitas kerja dengan pola WFO secara bergantian atau WFH hingga perilaku sosial keagamaan yang berbeda dengan situasi sebelumnya.

$$
\text { Perubahan situasi ini juga }
$$
dirasakan oleh orangtua yang memiliki anak berkebutuhan khusus, mereka juga memiliki tantangan yang besar dalam beradaptasi di situasi pandemi. Kebijakan-kebijakan yang membatasi interaksi dan mobilitas masyarakat menyebabkan para orangtua yang memiliki anak berkebutuhan khusus sulit mendapatkan layanan professional bagi anaknya seperti saat tidak terjadi 
pandemi. Kondisi tesebut menyebabkan orangtua harus mengambil peran sebagai terapis, guru, sekaligus pengasuh bagi anaknya yang memiliki kebutuhan khusus. Situasi yang dihadapi oleh orangtua yang memiliki anak berkebutuhan khusus di masa pandemi ini merupakan situasi yang sulit dan tidak mudah untuk dihadapi. Disatu sisi, sebagian besar orangtua belum terbiasa untuk menangani semua kebutuhan akademik anak mereka secara langsung. Para orangtua yang tidak terbiasa akan mengalami kesulitan untuk memahami strategi yang tepat untuk menangani anak mereka saat belajar. Disisi lain, orangtua yang bekerja tentunya harus mengelola waktunya sedemikian rupa untuk dapat menyelesaikan beban tugas di pekerjaannya dan mengasuh anaknya di rumah. Apalagi, jika orangtua tersebut memiliki anak lebih dari satu, tentu mereka harus membagi waktu dan tenaga mereka untuk kebutuhan yang lebih banyak lagi.

Proses penyesuaian diri orangtua yang memiliki anak berkebutuhan khusus di masa pandemi ini dapat memberikan dampak psikologis. Oleh karena itu, dibutuhkan kemampuan orangtua untuk dapat beradaptasi dan tetap teguh dalam situasi sulit ini. Kemampuan ini disebut dengan resiliensi (Reivich \& State,
2002). Lebih lanjut lagi Reivich dan State menjelaskan bahwa resiliensi ini dibangun dari tujuh kemampuan yang berbeda, yaitu: regulasi emosi, pengendalian impuls, optimisme, empati, analisis penyebab masalah, efikasi diri, dan peningkatan aspek positif. Setiap individu memiliki kapasitas untuk menjadi resilien. Resiliensi adalah ide yang mengacu pada kapasitas sistem dinamis untuk bertahan atau pulih dari gangguan (Masten, 2007). Kemampuan resiliensi ini menitikberatkan pada kekuatan individu untuk dapat menghadapi situasi yang sulit (Hermawati, 2018). Individu yang resilien akan merasa mampu mencapai tujuan dalam situasi yang sulit, percaya pada diri sendiri, memiliki toleransi terhadap emosi negatif, tehar dalam menghadapi stress, cepat melakukan coping, menerima perubahan positif, dan mampu beradaptasi serta dipengaruhi aspek spiritualitas. Herrman, Stewart, Diaz-Granados, Berger, Jackson dan Yuen (2011) menyebutkan bahwa resiliensi meliputi bersumber dari beberapa hal diantaranya ialah : pertama, faktor kepribadian, meliputi karakteristik kepribadian, self-efficacy, selfesteem, internal Locus of control, optimisme, kapasitas intelektual, konsep diri yang positif, faktor demografi (usia, jenis 
kelamin, suku), harapan, ketangguhan,regulasi emosi, dan sebagainya. Kedua, berasal dari faktor biologis. Serta, yang terakhir ialah faktor lingkungan.

$$
\text { Ketika orangtua anak }
$$
berkebutuhan khusus dapat menghadapi realitas yang terjadi dengan segala permasalahan yang terjadi selama mendampingi anak berkebutuhan khusus belajar dari rumah, maka ia dapat dikatakan sebagai individu yang resilien. Wood, Joseph, dan Linley (2007) menyebutkan bahwa individu yang bersyukur akan mampu melihat kehidupannya secara positif dan optimis dalam berusaha mengatasi setiap permasalahan yang dihadapi. Berdasarkan hal tersebut, tujuan penelitian ini adalah menggambarkan resiliensi orangtua anak berkebutuhan khusus dalam mendampingi untuk school from home di masa pandemi Covid-19.

\section{METODE PENELITIAN}

Desain Penelitian

$$
\text { Metode penelitian yang }
$$

digunakan dalam penelitian ini adalah survei dengan pendekatan kuantitatif. Proses pengambilan data dengan menggunakan kuisioner yang berisi tentang pernyataan dengan alternatif jawaban. Format respons menggunakan skala interval satu hingga lima.

\section{Populasi Partisipan}

Partisipan dalam penelitian ini ialah orangtua anak berkebutuhan khusus. Teknik penentuan partisipan dilakukan dengan teknik purposive sampling, ditentukan sejumlah kriteria dalam prosesnya. Jumlah partisipan yang terlibat dalam penelitian ini sejumlah 66 orangtua anak berkebutuhan khusus.

\section{Instrumen Penelitian}

Pengumpulan data dilakukan dengan teknik menyebarkan kuisioner yang berisi pernyataan daftar tertulis tentang resiliensi. Instrumen pengumpulan data dalam penelitian ini ialah skala resiliensi orangtua anak berkebutuhan khusus. Butir instrumen yang disusun dan dikembangkan dari teori resiliensi dan pengasuhan (caregivers' resilience and the Resilience) oleh Davis (1999). Validitas konsep dilakukan melalui tiga orang expert judgement dengan pernyataan bahwa instrumen layak untuk digunakan. Validitas empiris dilakukan dengan melakukan uji coba pada 40 orang responden di luar populasi. Hasil menunjukkan bahwa semua butir instrumen dinyatakan baik. 


\section{HASIL DAN PEMBAHASAN}

Data interval diperoleh dari 66 responden orangtua anak berkebutuhan khusus yang telah mengisi skala resiliensi. Hasil perhitungan statistik deskriptif dapat dilihat melalui tabel berikut ini :

\begin{tabular}{|c|c|c|c|c|c|}
\hline \multicolumn{5}{|c|}{ Tabel 1. Analisis Deskriptif } \\
\hline & N & Minimum & Maximum & Mean & Std. Deviation \\
\hline VAR00001 & 66 & 29.00 & 57.00 & 43.151 & 5.55599 \\
& & & & 5 & \\
\hline $\begin{array}{c}\text { Valid N } \\
\text { (listwise) }\end{array}$ & 66 & & & & \\
\hline
\end{tabular}

Dari hasil perhitungan tersebut, kemudian dibuat pengkategorian pada penelitian ini, seperti yang disajikan pada tabel 2 .

Tabel 2. Kategori Penilaian

\begin{tabular}{|c|c|c|c|c|c|}
\hline Mean & \multicolumn{2}{|c|}{ SD } & Hasil & Kategori & \\
\hline 43 & 1,8 & 6 & 53,1523 & TS & 53 \\
\hline 43 & 0,6 & 6 & 46,4851 & T & $46-53$ \\
\hline 43 & 0,6 & 6 & 39,8179 & S & $39-46$ \\
\hline 43 & 1,8 & 6 & 33,1507 & R & $33-40$ \\
\hline \multicolumn{7}{|r|}{} & $<\mathrm{R}$ & RS & $0-33$ \\
\hline
\end{tabular}

Berdasarkan hasil pengkategorian penilaian, diperoleh hasil bahwa sebesar $3,03 \%$ orangtua anak berkebutuhan khusus memiliki resiliensi yang tinggi sekali. Kedua, sebesar 3,03\% orangtua anak berkebutuhan khusus memiliki resiliensi yang tinggi. Ketiga, sebesar $36 \%$ orangtua anak berkebutuhan khusus memiliki kategori resiliensi yang sedang. Sedangkan, hasil lainnya menunjukkan
12\% dengan kategori rendah dan $46 \%$ kategori rendah sekali. Jadi, dapat disimpulkan bahwa orangtua anak berkebutuhan khusus memiliki resiliensi pada kategori rendah sekali yakni sebesar 46\% (31 orang). Tujuan dari penelitian ini ialah untuk menggambarkan resiliensi orangtua anak berkebutuhan khusus saat pandemi Covid-19.

Secara umum, orangtua anak berkebutuhan khusus memiliki resiliensi dengan kategori rendah sekali. Situasi pandemi Covid-19 dengan berbagai dampak yang terjadi dapat mempengaruhi kondisi psikologis seseorang. Individu merasa kebingungan, sedih, frustasi dan marah karena memikirkan situasi yang tidak jelas. Hal ini tentunya juga dirasakan oleh orangtua anak berkebutuhan khusus, mereka membutuhkan waktu untuk menyesuaikan diri dengan berbagai situasi yang baru saat terjadinya pandemi. Orangtua anak berkebutuhan khusus menyesuaikan dengan proses pendampingan anak berkebutuhan khusus yang biasanya dilakukan oleh guru atau terapis saat di sekolah kemudian kembali dilakukan oleh orangtua saat dirumah. Kondisi ini tentunya membuat orangtua menjadi kawatir atau cemas karena bisa saja tidak terbiasa dengan proses yang dihadapi saat ini. Oleh karena itu, 
orangtua anak berkebutuhan khusus perlu lebih resilien, Keye \& Pidgeon (2013) menyebutkan bahwa dengan cara meningkatkan pengetahuan untuk adaptif dan belajar untuk mengatasi situasi yang dapat merugikan adalah upaya agar lebih resilien. Dukungan keluarga, khususnya suami atau istri serta keluarga terdekat dapat membantu untuk lebih resiliensi. Dukungan ini dapat berupa cinta, kasih sayang serta support yang diberikan dalam bentuk edukasi. Faktor lainnya disebutkan bahwa faktor internal khususnya sikap optimis serta percaya diri dapat membantu individu untuk lebih tangguh dalam mengatasi rintangan (Wahidah, 2020).

Temuan ini tentunya memiliki implikasi praktis bahwa dalam mendukung proses pendampingan belajar anak berkebutuhan khusus ketika menjalankan school from home saat pandemi Covid-19, orangtua perlu memiliki resiliensi yang baik. Agar nantinya dapat mendukung serta menimalisir permasalahan yang ada ketika berperan sebagai guru atau terapis anak berkebutuhan khusus saat dirumah.

\section{PENUTUP}

\section{Simpulan}

Berdasarkan hasil dan pembahasan secara umum, resiliensi orangtua anak berkebutuhan khusus memiliki kategori rendah sekali yakni sebesar $46 \%$. Faktor yang dapat melatarbelakangi munculnya kondisi ini ialah orangtua berada dalam proses adaptasi untuk menghadapi situasi ini. Selain itu, adanya kebingungan dalam penanganan anak berkebutuhan khusus saat muncul masalah dalam belajar dan perilaku dapat membuat orangtua lebih frustasi. Sehingga, belum tercipta kemampuan diri yang lebih resiliens dalam menghadapi berbagai situasi. Beberapa saran dan rekomendasi dari penelitian ini diantaranya yaitu pertama, untuk lembaga pendidikan / sekolah dapat membangun kolaborasi yang aktif dengan orangtua dalam menjalankan school from home. Kedua, perlu dilakukan kajian lanjutan oleh peneliti selanjutnya terkait bagaimana mekanisme pertahanan diri yang dilakukan oleh orangtua anak berkebutuhan khusus saat pandemi Covid-19. Ketiga, dapat dilakukan kegiatan pengabdian masyarakat untuk orangtua anak berkebutuhan khusus agar lebih resiliensi dalam memberikan pendampingan pada anak berkebutuhan khusus saat pandemi Covid-19.

\section{Ucapan Terima Kasih}

Penelitian ini merupakan bagian dari pendanaan Hibah Perguruan Tinggi di lingkungan Universitas 17 Agustus 
1945 Surabaya. Peneliti mengucapkan terima kasih pada Univeristas, LPPM, Tim Peneliti dari Fakultas Psikologi Universitas 17 Agustus 1945 Surabaya, Mahasiswa serta partisipan yang terlibat dalam proses penelitian.

\section{DAFTAR PUSTAKA}

Hermawati, N. (2018). Resiliensi Orang Tua Sunda yang Memiliki Anak Berkebutuhan Khusus. Jurnal Psikologi Islam Dan Budaya, 1(1), 67-74. https://doi.org/10.15575/jpib.v1 i1.2345

Herrman, H., Stewart, D. E., DiazGranados,N., Berger, E. L., Jackson, B., \& Yuen, T.(2011). What is resilience? CanJpsychiatry, 56(5), 258265.

Keye, M. D., \& Pidgeon, A. M. (2013). AnInvestigation of the relationship between resilience, mindfulness, and academic self-Efficacy. Open Journal Of Social Sciences, 1(6), 1-4. doi: 10.4236/jss.2013.16001

Masten, A. S. (2007). Resilience in developing systems: Progress and promise as the fourth waves rises.Development and Psychopatology. 19. 921930.doi:10.1017/S0954579 407000442

Relvich, K., \& Shatte, A. (2002). The resilience factor. New York: Random House, Inc. psychological resource of grateful people. Journal of Social and Clinical Psychology, 26(9), 10761093, https://doi.org/10.1521/jscp.20 $\underline{07.26 .9 .1076}$

Wahidah, E. Y. (2020). Resiliensi Perspektif Al Quran. JURNAL ISLAM NUSANTARA, 2(1), 105-120.

WHO. (2020). Coronavirus disease (COVID-19) outbreak situation. (Online) Tersedia :https://Covid19.who.int/ (Diakses : 26 Oktober 2020)
A. M., Joseph, S., \& Linley, P. A. (2007). Coping style as a 